\title{
Relief: Observations on Creative Nonfiction as Pedagogy
}

\author{
Mark Silverberg
}

\begin{abstract}
"Relief: Observations on Creative Nonfiction as Pedagogy" offers a case study in the possibilities of using creative writing as a pedagogical tool with ESL students. Analyzing the experience, comments, and creative work of a Chinese nursing student named Wei Wan at Ryerson University, the essay explores the benefits of personal writing and peer workshops as tools for self-exploration, aesthetic appreciation, and confidence building. While urging teachers to see the advantages of this methodology, the paper also reflects on the literary values of creative work in hybrid, non-standard English forms.
\end{abstract}

As a teacher of literature and occasionally creative writing at Cape Breton University (a small institution with a traditionally homogenous, English-speaking, population), I hadn't given much thought to the possibilities of creative writing and second-language learning. That changed this past summer when I had the opportunity to teach a class at Ryerson University, a large, urban institution in downtown Toronto with an ethnically diverse student body including many new immigrants. Since this creative writing course was classified as a "liberal arts elective," one that could be counted for credit by students in almost any program, the class attracted a diverse group from a wide range of majors. While I didn't design the class for "second-language learning" as such, it turned out that some of the students who benefitted most from the class had chosen it with exactly this goal in mind.

This essay explores the experience, comments, and creative work of one such student, a Chinese nursing student named Wei Wan, whose writing I'd like to consider as a case study in the possibilities of using creative writing, particularly creative nonfiction, as a pedagogical tool. Wei Wan produced two remarkable personal essays, one of which is reproduced below. After the course was completed, I asked her to share some of her thoughts and recollections about the class.

I think Wei Wan's writing is illustrative in two ways: first, her experience and comments attest to the potentially transformative powers of writing and creative workshops as tools for self-exploration, aesthetic appreciation, and confidence building. Second, her final pieces (particularly before they were subjected to rigorous "correction" for syntax and grammar) reveal the stylistic nuance possible in a hybrid English that educators may be too quick to correct out of existence. Here Wei Wan reflects on choosing the course and her experience of the first few classes:

This past spring, I needed to choose an elective. Since English is my second language, writing is really painful. I enjoy writing in my native language but transferring that to English is very difficult. Therefore, I wanted a course that would improve my English skills and be interesting at the same 
time. Because of English being my second language, I hesitated and really struggled with making the decision to sign up. In the end, I really wanted the chance to improve so I joined the class.

What I learned in the first class and second class astonished me. The professor outlined some guidelines for writing. The methods, such as keeping your hand moving, losing control without thinking about punctuation, spelling, grammar, and on and on, were contrary to everything I thought I already knew. This amazed me because I had always focused on punctuation, spelling and grammar while writing. It caused me stress and it made writing a really laborious task. Thinking of the basic rules of writing disturbed my thought flow when I was trying to write.

The method I use with students develops out of what the Surrealists called automatism. Its goal is to short-circuit the barriers of reason and decorum by writing continuously for a set period of time, without letting the hand stop. "Automatic writing" is all about flow. ${ }^{1}$ It is a method of writing without rules, whether those of the "internal editor" (who tells us our writing is not good enough for one reason or another) or those of Standard English (whose requirements can be equally paralyzing for a secondlanguage learner). As Wei Wan puts it, succinctly and non-standardly, "During the course I followed these suggestions and really helped me to feel more freedom while writing." That fundamental freedom, about which little can be said, but from which much can be learned, is at the heart of what I wanted to happen for my students.

Another important method for this class, long known to English teachers and students, but frequently unrecognized by students in other disciplines, is writing from and about personal experience. My exercises and writing prompts invite students to explore intimate material, an emotional space that is often foreign in their academic experience.

In class, the professor suggested some topics for non-fiction writing practice. I had never thought about writing about such topics as describing a person, an action, best gift, or some memory. From my school year recollections back in China, we were never asked to write anything creatively, not even in Chinese class. So at the beginning, the topics to choose for writing didn't seem significant or deep enough. How wrong I was.

I remember, in the second class, the instructor requested us to write a description of a person we knew and to do it within 5 minutes. I chose to write about my mother. I thought I would have lots to write but my brain went blank when I started. I simply described my mother's health condition and the two days prior to her passing. I continued to write several sentences and felt my brain empty again.

As revealed in the following narrative from Wei Wan, "Relief," that blankness evolved into many pages of deeply felt, meditative prose. Using the language that came naturally to her, ignoring the imperatives (cultural, moral, grammatical) that would restrict flow, she allowed the piece to grow. I think there were several things that helped Wei Wan break though the initial barrier of silence. The first is the practice itself: writing automatically, "unthinkingly," on a regular basis. Wei Wan explains,

Another writing technique I learned was to foster good writing habits. This meant I had to practice regularly and be faithful to the schedule. . . After the first class, I set aside three to four hours every Monday and Tuesday to write or polish a piece. If I did not finish, I would continue on the following Monday and Tuesday... The overall outcome surprised me. Every time I wrote, I could 
sense that my thoughts were flowing easier and I was less concerned about the quality of English and more focused on the story. It was more fluid than before when I wrote.

The Surrealists believed this fluidity marked the opening of the unconscious. They saw automatism as akin to a form of dreaming, rather than a form of logical, rule-bound thought. The method of "feeling more freedom while writing" can only be learned by repeated experience: by regularly, unceremoniously opening a space for the unsaid, or the not-yet-said, or the repressed.

Wei Wan describes her return to writing about her mother from this vantage point:

I re-started my first commemorating piece to recall my mom's life. Some feelings I have never revealed to my family. I wanted to hide them inside me as my Chinese culture teaches us to do. Some thought and images of my mom have existed in my mind and have never changed. But over time I was afraid that these would fade away, and be forgotten. However, I was surprised that the more I wrote these thoughts, the more other thoughts and images popped into my head.

This process of reliving and rewriting, as Wei Wan tells us and shows us in the following piece, is both risky and enlivening, a "relief" in many senses of the word:

\section{Relief (by Wei Wan)}

Shane, my mom, was an active and energetic woman with black eyes and hair. She was beautiful, gorgeous and curvy with slim figure. She liked all the fresh and fashionable things and always tried to learn and use them. She always hid her smile under a serious facial expression. It scared my classmates during my childhood. When they saw her, it was as if a rat met a cat. She had a strongly compelling laugh, which spread to people around her. She spoke briskly and persuasively.

I am very proud of her. Whenever I hear someone talking about my mom, my chin tilts up and up with a smile. I guess people could not see my face but only my nostrils at that time. In my memory, she had always spent time with me until I fell asleep at night on average days. Sometime I woke up and did not see her, I had never hesitated shouted "mom ", then mom seemed to appear immediately and jumped onto my bed out of nowhere and then stayed with me. I had never thought she would ever no longer respond to me when I called her. I had never thought she would leave me.

When I was a child, I followed my mom all the time. People liked to call me "mom's tail" as a nickname. She liked to call me around when she arrived home from work. Because I am her third child, she always called me from her eldest child's name and ended with mine. So my name was "How-Hey-Anne."

One day I hid in a wardrobe when she arrived home. I did not show up after her call. She detected that my schoolbag was at home, therefore assumed I was home as well. She looked for me around the house while called my name. When she found me, we stared each other and laughter filled our home. I liked to play this game because I like to hear her voice ringing like a song. The game did not continue right until the wardrobe could not fit my body, but I still waited for her calling and suddenly appeared in front of her; watched sparks emitting from her eyes, and heard laughter flying out of her mouth.

She is like a magician when I want to eat snacks. She can grab anything if I want them. 
When I said, "Mom, I am hungry." A candy, an apple or a piece of cake immediately came out from her hands. I laughed.

When I asked her, "Where did you get me?" or "Where was I born?"

She laughed and said, "Oh. I got you from a garbage bin." But something she said, "When I gave your birth, you cried like a boy. I was disappointed. But nurse said, 'she is a girl.' I was really happy. I have a girl!"

I always laughed because I could feel her happiness. She always laughed when she talked with me.

My elder brother said, "Our mom is an excellent lady, I have never seen another like her in my life."

In 1984, I was 13 years old; my mom had some weird signs, such as urgent bowel movement, and lightly abdominal pain. She did not see a doctor until she could not stand her pain. To figure out what happened to her took 3 months to get a diagnosis. It was cancer. She stayed in the hospital and had a basic treatment for pain.

When I went to the hospital after school, I still could see her smile with dark circles around her eyes. I did not know how she spent every long night, she had never mentioned how. She promised me that she would buy beautiful clothes for me and cook delicious foods for me after she's discharged. I had never doubted how she would break a promise. Three months later, my mom and family decided to have a surgery to remove the tumor. This surgery was unsuccessful, because cancer cell already spread all over the body. No hope was to be anticipated.

She lived at a unit where people diagnosed with terminal illness would stay. There was a three-single-bed room. Her room had two other people while she moved here.

At her first day of moving into the room, we accompanied, and pushed the door to enter in. We saw two residents were lying in their own single beds. They opened their eyes, turned their heads to face to the opening door, indifferently looked at us for a very short time and then closed their eyes. Their families were sitting beside their beds and smiled when they saw us. No words of welcoming or expression came out from them.

The room was very quiet. Shane spoke about her job and life in the future if she recovered when we stayed there. The unit did not allow family to stay overnight. We took turns to stay with her during daytime. She always talked about her future. She said she would buy beautiful clothes for me, and she would see her sons' lucky future.

She was very independent. She went to washroom and dealt with her personal hygiene by herself. She had never asked for help even though she was very weak. She had never said how she was tormented with her pain. She only asked, "please, give me a shot," and then lied in the bed very quickly for two to three hours without any words.

The unit was in shortage of staff. One nurse would have managed 60 patients. The doctor and hospital gave the permission allowing family to give painkillers because Shane asked for a shot in every 1-2 hours period. My father and my elder brother (Hey) even learned how to give a painkiller shot. 
Later, Hey told me with tears filling his eyes, "her skin is like a hard board because the tiny needle holes are all over her arms, thighs and her buttocks, her bone protrude over her body because no more fat can be felt. I don't know where I can put needles in. I don't even know if the shots work." No treatment was provided aside from the painkillers.

After 9 o'clock at night, we left her to stay lonely. She had never said how her night was. She always looked at door with smile when I opened the door to see her.

One day, one of the beds was empty when I went there. My mom became a little bit quiet. She started to ask me to assist her with personal hygiene. She could stand by herself for a short time. She needed our arms when she walked between her bed and washroom. She could not walk without assistance. She lied in the bed all the time.

I asked my father and brothers, "How does mom do when I was not here."

They gave the same answers quietly, "No changes. She can do everything by herself."

It was February 19, 1985. At 9 o'clock, we left away from the hospital and stayed home together to celebrate the Chinese New Year's coming. Around 10 o'clock, we heard someone knocked our door. I was downstairs and opened the door.

"Mom?! Why are you here?!" I surprised.

"Mom is coming. Mom is back to home." I turned my head, looked up the stairs and raised my voice.

She was excited and laughing when she saw the door opening. She gave me a big hug and whispered, "Yes, I am back home."

She seemed like a very healthy and beautiful lady. My mom was back. Yes! She was back.

My father and brothers were downstairs and looked at her. They were surprised. She was upstairs with a left hand against the wall. I doubt if my mom recovered.

She was sitting in a chair beside my father and faced to her children in the living room. My brothers and I were on our knees facing to them. The candles were lit. The red lanterns were lit.

We said, "Xin Nian Kuai Le (Happy New Year)! Gong Xi Fa Cai (Hope to have a rich and flourish year)!"

My mom and my father said, "Wish you have a flourish year. How and Hey have a good achievement from work. Anne has good grades from school."

And then my mom gave lucky bags to each of us like every other previous year. We were very happy. My mom did not stop her smile during the dinner. She did not stop looking at us even though she was eating.

After the dinner finished, my father said seriously to my mom, "you have to back to the hospital. We do not have any medicines, syringes or needles at home."

The smile gradually disappeared from her face. She stayed at home that night and my father brought her to the hospital next day. 
When I went to school in the morning, one of my neighbours asked, "Is your mother at home? I saw her walking toward your home last night. She pressed her two hands against wall to walk. I asked if she needs help. She shook her head. Why did nobody accompany her?"

One month later, another bed was emptied. She lost her laughter and became quieter. I could sometimes see her weak smile. She still asked for my assistance, but had never asked my father or my brothers for.

She still liked to look at door when the door opened. The smile faded little by little, bit by bit. Occasionally, she said, "I will buy beautiful clothes for you. I will cook delicious food for you," she had a short pause, and said, "If I am getting better." I had never second guessed her words.

Three months passed after Chinese New Year, she was lying in her bed. A yellowish face, eyes deeply sunken, cheekbone highly raised, lips without any clear border and pale. Because there was not any fat underlying the face, her eyes appeared very large and dark. She seemed not take interest in anything and quietly waited for the death approaching. She did not try to talk because cancer cells ate most of the nutrition from her body and continuous pain tortured her all the time. She lost her energy. She was not able to sit, stand, or walk. She was not able to clean by herself. Most days, she spoke one or two words during the day. She gradually stopped asking to have pain medications. Pain seemed to be gone away from her. Her face became peaceful.

It was May 16, 1985. The room was still quiet and empty. Only my mom and I were at room. I read a book and sat beside her. She opened her eyes widely; it looked like they were occupying half of her face. There was a light igniting in her eyes.

She looked at the door, asked me to open it, and mumbled, "someone's coming to bring me to heaven."

She took a deep breath and tried to raise her voice hastening me to open the door, but the voice still mumbled, "open the door... someone's coming ... and they will pick me up to go anywhere."

I opened the door, but there was no one there. She tried hooking over her neck to look outside the door, but failed to do so. Then she closed her eyes and sighed. The second day, she stopped her breathing and quietly left me without a word. Perhaps there was not only tiredness, but also relief.

A nurse told us, "Your mom was always moaning over the night since her first day at the hospital."

"She refused to have pain medication. I assumed she wanted her family to stay with her and give medication to her," another nurse said.

Yes, pain had never left her side. Yes, I forgive her to break her promise. Yes, she is free now.

How happy I was at the time,

How painful I become now...

You are free because I permitted

You are relieved because I let you go

Good-bye. 
After she completed the course, I invited Wei Wan to write about her experience of the class, and her observations may offer insight for teachers. She talks about the importance of reading literature in class and studying models - though not of grammatical correctness, expository control, or organizational modes (compare/contrast, etc.), as had been her experience in previous English classes-but rather models of sophisticated, engaging imaginative writing:

The following class, the instructor lectured on how to read a story and how to understand the structure of a story. I realized that my first draft could be expanded. Some depth could be added to the piece. I have learned that some elements of a story are very important in order to form a story, such as setting, plot, theme, climax, resolution, and so forth. The professor guided and encouraged students to write down their thoughts. His words enlightened me to write my thoughts and explore my feelings.

I hope, as Wei Wan suggests, that my method is not prescriptive but descriptive. Effective creative writing comes from absorbing, often osmotically, the nutrients of other effective writing. Offering practicing writers a way to read with an eye, not so much to "objective" analysis as to understanding the nuts and bolts of writers' techniques and gestures, puts a new kind of practical emphasis on structure. Writers want to understand the artifices other professionals have erected in order to build their own "machines made out of words" (p. 256), in William Carlos Williams' (1969) felicitous phrase. One particular assignment I offer my creative writing students is to complete an "emulation project." Students choose a writer they admire and read a significant amount of this person's work, while keeping a journal of their responses, questions, thoughts, favorite lines, and other forms of "talk back." Their final project is to produce their own work in the same genre (a set of poems, short story, or piece of creative nonfiction) that imitates and emulates the voice and vision of that writer.

Another important part of the creative writing experience, which differs from the methodologies students in academic programs are familiar with, is the peer workshop. Working with a supportive group of peers, reading one's own work aloud to others and sharing reactions, is a unique and personal event. It is an encounter that encourages bonds among a community of workers engaged in what is usually seen as a solitary task. Here are Wei Wan's comments on workshops:

The peer critiquing process workshops were very useful and helpful for writing. I was lucky that I had group members to help. They asked me insightful questions and reviewed my piece ... . The brainstorm sessions from the very beginning suddenly opened my thoughts and pushed me to think beyond what I normally would have done. Based on those questions and suggestions they gave me, the second revision developed into a more filled out piece. Later, I did third and fourth edition to polish off the piece.

Finally, and maybe most importantly, "Relief" offered just that: a complex, subtle, self-directed forum to explore emotions that may not be given time or space in students' busy lives:

I was very happy to discover that I am able to express my emotions through writing. What I revealed in my story about my mother were thoughts which were deeply buried in heart and had never realized them before. I wrote "Relief" to reveal my feeling and relieve my soul. Through the writing process cycle, of repeatedly write-read-rewrite-reread, I felt more and more 
relieved. My mom's image was clearer in my mind. I was happy that through this writing course I have remembered her more than I thought I did.

In part, this transferable relief is not only personal, but also built into the piece structurally in a way that allows it to be shared and to produce a cathartic effect in readers.

Part of that function has to do with the accidents created in the automatic writing process. One of the things that immediately attracted me to Wei Wan's early (minimally edited) work was its unique, non-standard way of expressing itself, a way that sounds "off" for most native English speakers. But this off-ness has a productive artistic value in the way that it defamiliarizes language-making it feel awkward, unsettled, non-transparent. Defamiliarization happens, as Russian formalist Viktor Shklovsky (1965) tells us, when our standardized habits of perception and processing are challenged:

Art exists that one may recover the sensation of life; it exists to make one feel things. .... The technique of art is to make objects 'unfamiliar,' to make forms difficult, to increase the difficulty and length of perception because the process of perception is an aesthetic end in itself. (p. 12)

Writing by non-native speakers has a unique and particular way of making language perceptible by slowing down readers' processing when subjected to non-standard forms. And that slowing down allows for a different, sometime deeper, kind of engagement.

English instructors should perhaps pause even longer on these awkward, unfamiliar forms which offer both an opportunity and a danger in students' work. One part of the instructor's job is to teach Standard English and "protect" students from deviating. Another part is to foster and encourage original expression. With this in mind, creative language teachers should also, at least in some instances, interrogate their tendencies to correct out of existence what may well be most interesting and unique in a non-standard piece: that is, the accidental stylistic quirks that may be grammatically incorrect but creatively productive.

Take these sentences from Wei Wan's third draft of "Relief," describing the narrator's belief in her mother's presence:

Sometime I woke up and did not see her, I had never hesitated shouted 'mom $\sim$ ', then mom seemed to appear immediately and jumped onto my bed out of nowhere and then stayed with me. I had never thought she would ever no longer respond to me when I called her. I had never thought she would leave me.

Nonstandard syntax, run-on sentences, double negatives, and grammatically awkward repetition have the effect of defamiliarizing Standard English patterns. Instead of the phrase, "I always thought she would be there for me when I called her" (which is, in fact, Wei Wan's fourth revision, after instructional help), in her third revision she offers the reader a structure which is much more powerful. Longer, sadder, syntactically and emotionally troubled, the sentence calls for stronger reader engagement and ultimately has a more compelling effect as readers struggle through all the linguistic knotting: "I had never thought she would ever no longer respond to me," to arrive at the final poignant clause, "when I called her." 
Minor errors or omissions also create poetic opportunities for readers. Moments of divergence from Standard English call for pauses, a "prolonging of perception" (in Shklovsky's terms) that may allow new possibilities to emerge. Take, for example, Wei Wan's description of the game of hide-and-seek: "When she found me, we stared each other and laughter filled our home." Many readers will silently amend the passage to, "When she found me, we stared at each other," suggesting a moment of longing fulfilled. But the gap that "stared each other" prompts might also be filled in other ways. It may suggest an underlying theme, a buried phrase: "we stayed" or "stayed with each other." This dormant desire, unearthed by shifting " $r$ " to " $y$," foreshadows a deeper game of hide-and-seek the text plays with the missing mother. In search of relief from her loss, the text not only stares, but also stores the mother; it stops her in this moment of health, so both can stave off the already acknowledged future. At the same time, the game of hide-and-seek stirs up these secret feelings. The passage continues: "I liked to play this game because I like to hear her voice ringing like a song. The game did not continue right until the wardrobe could not fit my body, but I still waited for her calling."

"Until the wardrobe could not fit my body" is a fortuitous inversion of grammatical sense, which would normally call for the body (grown larger) to no longer fit in the wardrobe. But the "error" again multiplies meanings: The phrase marks not just the end of the game of hide-and-seek, but a foreshadowing of other endings. We might be reminded of the "beautiful clothes" Shane promises her daughter which will never be bought, will never fit the narrator's body or wardrobe. Or we might be prompted to consider the way Shane, too, fits her body less and less comfortably as her disease progresses: "A yellowish face, eyes deeply sunken, cheekbones highly raised, lips without any clear border and pale." The wardrobe that could not fit my body reminds us of both women's growing sense of being ill at ease in a body suffering from sickness or mourning. It also calls to mind the need for relief or escape from this oppressive space: "She took a deep breath and tried to raise her voice, hastening me to open the door, but the voice still mumbled, 'open the door... someone's coming ... and they will pick me.'"

One of the fortuitous effects of Wei's uncertain command of English pronouns is to link the narrator and her mother. By creating grammatical confusion at times about subjects, the text brings the two closer together. For example, in the phrase "After 9 o'clock at night, we left her to stay lonely," to whom does "stay lonely" apply, the mother or the daughter? The ambiguity amplifies the point of their joint loneliness, whether staying in the hospital or staying home. Again, in the final passage, "you" and "I" are elided in ways that cause productive confusion:

You are free because I permitted—You are relieved because I let you go

Both mother and daughter are freed from physical and psychological pain. Both are relieved from the burdens of holding on to something that can no longer be held. Wei Wan's relief is worked through in creative writing-by breaking the rules of silence and decorum. The free writing process allows her to process her grief and her story in her own way, beyond the canons of culture or grammar, and it is this process that leads to the relief of both: "You are relieved because I let you go." I want to end on Wei's final words about the course. They highlight both the process of improving writing (the ostensible purpose 
of the course for Wei Wan and for many students) and of improving life quality through the subtle restructuring that telling our own stories can achieve.

I am very satisfied with my choice of taking this course. It's because of this course I was able to write two pieces from my childhood that had such meaning for me. I do not know if I will continue writing creatively for joy and pleasure. But in the end, I have crafted a piece that I am very proud of called "Relief." I can hand this piece down to my daughter and my mom's legacy will continue on. This course gave me that chance to bring my mom to life again.

\section{Acknowledgment}

I want to thank my student Wei Wan, whose dedication to her own process and to our Creative Writing course through the Chang School of Continuing Education at Ryerson University was the impetus for these observations. I prepared this research while I was a Research Associate at the Modern Literature and Culture Research Centre at Ryerson University, Toronto, and am grateful for the support.

\section{Note}

1. Most teachers of creative writing will be familiar with this method as developed and explained by Goldberg (1986) in her best-selling creative writing book Writing Down the Bones.

\section{References}

Carlos Williams, W. (1969). Selected essays of William Carlos Williams. New York, NY: New Directions.

Goldberg, N. (1986). Writing down the bones: Freeing the writer within. Boston, MA: Shambhala.

Shklovsky, V. (1965). Art as technique. In L. T. Lemon \& M. J. Reis (Eds.), Russian formalist criticism: Four essays. Lincoln, NE: University of Nebraska Press.

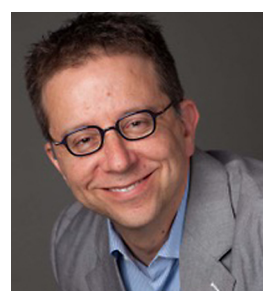

Mark Silverberg is an Associate Professor of English in the Department of Literature, Folklore, and the Arts at Cape Breton University and an Adjunct Professor at Ryerson University. He is the author of The New York School Poets and the Neo-Avant-Garde: Between Radical Art and Radical Chic (Ashgate, 2010) and editor of New York School Collaborations: The Color of Vowels (Palgrave/ MacMillan, 2013). He is also the author of a prize-winning collection of ekphrastic poems, Believing the Line: The Jack Siegel Poems (Breton Books, 2013, Eric Hoffer Book Award). 